\title{
AMERICAN FIRE WASTE AND ITS PREVENTION
}

\author{
By Frankin H. Wentworth, \\ Secretary-Treasurer, National Fire Protection Association.
}

The European peoples point to the fire waste of America as evidence that the American people are the most careless and irresponsible individuals in the civilized world. This is not a flattering tribute. It behooves us to inquire if the charge be true, and if so how we may mend our unpleasant reputation. Statistics show that in the United States and Canada the fire waste is roughly ten times as much per person as in Europe. This contrast is partly explained by the facts that there are more people in Europe upon whom to figure this percentage and that more buildings in America are constructed of wood. Outside of Constantinople with its unsanitary conditions, European cities are seldom visited by such sweeping fires as have devastated the American cities of Chicago, Boston, San Francisco, Atlanta, Baltimore, Chelsea, Salem, Paris, Tex., Nashville, Augusta and others. American building construction is inferior to that of Europe in other respects. A poorly built city with numerous wooden buildings awaits only the right kind of a fire on the right kind of a night for its complete destruction.

Of the personal hardships, individual sufferings and economic disasters which follow the burning of a city, too many American cities can testify. The economic significance of these fires is not confined, however, to the cities that burn. Every fire, whether it consumes a whole city or only the roof or other portion of an individual house, has to be paid for. A burned house or city does not replace itself. Food, clothing and shelter are produced only by human effort, and labor expended in replacing waste is withdrawn from producing more things for the satisfaction of human needs; hence every fire makes every man's struggle for a living harder by compelling him to spend for his neighbor's waste what he might otherwise spend for his own comfort.

Our annual waste of $\$ 3$ per capita means that every man, woman and child pays $\$ 3$ a year for fire waste. That means that 163 
the man with the average family, his wife and three childrena family of five-pays $\$ 15$ a year fire tax. The United States government in its reports adds to this fire waste the cost of maintaining fire departments, which is as much more. This means $\$ 30$ a year to the average family. If on some blue Monday in every year a representative of the government were to come around and ask us each for a check for $\$ 30$ to pay our share of the national carelessness, then we should realize what we pay. But we do not realize that we pay it, because this tax is indirect.

The big manufacturers and the big merchants know that this fire expense is a tax. They equip their premises with automatic sprinklers. They put in protective apparatus. They get the lowest insurance rate they can because it helps them to compete; but the man in the street, the ordinary man, does not know how this fire waste is paid. Take wool, for example. Wool in the warehouse is insured-that is a tax. It is insured in transportation, and there it pays a fire tax. It is insured in the texile factory where it is worked up into cloth. It is insured in the clothing store, insured in the tailor shop, in the department store, and all the way along this fire tax is added to the cost, and when we buy a coat, we pay it. Every stock of goods that is insured carries this tax, and it is passed along to the ultimate consumer. The masses do not know that they pay it. They do not realize that when they buy a hat, or a pair of shoes, or a suit of clothes, or anything which goes through the regular channels of industry-production, distribution and exchange - they pay this tax. Not realizing it, they are indifferent to fire. They think fire does not affect them.

The fire loss in the United States and Canada for the last ten years has averaged $\$ 230,000,000$ a year. What might we not do with that? We might build roads, canals, improve our harbors, build battleships - if we have no less mediaeval use for our money. We could do a great many things with $\$ 230,000,000$ a year. What country can stand a drain like that? Suppose we were to throw into the sea $\$ 230,000,000$ in wheat or corn or cotton, or lose $\$ 230,000,000$ out of our national treasury. Then we would realize that we are being impoverished by this waste. But we have lost the faculty of being moved by an ordinary fire. In Europe a $\$ 100,000$ fire shocks the entire continent. All the papers in Continental Europe comment on it, wanting to know how it occurred, 
who was responsible for it, whether the conditions obtaining in the city where it occurred can be found elsewhere, so that such a fire might be duplicated. But here in America, if we take up the morning paper and do not find reports of two or three $\$ 100,000$ fires we think it has been a dull evening!

We are the most careless people with matches on the face of the earth. In Europe, if you want matches you have to go where they are kept. In America matches are everywhere; on our bureaus; in our desk drawers; on the mantel-pieces; library tables; in all our old waistcoat pockets in the closets. If we wake up in the middle of the night and reach out and cannot find a match we feel insulted! And yet every match is a potential conflagration. Fire from a single match may burn a whole city.

The fire waste touches the pocket of every man, woman and child in the nation; it strikes as surely but as quietly as indirect taxation; it merges with the cost of everything we eat and drink and wear. The profligate burning every year of $\$ 230,000,000$ in the value of work of men's hands means the inevitable impoverishment of the people. This fearful loss, spread over the entire business world of America, is beginning to manifest its impoverishing blight. The people feel it without yet being awake to its cause. Their awakening is retarded by the prevalence of the foolish notion that the insurance companies pay this colossal tax. But how could they, and remain solvent? They are mere collectors and distributors of that portion of this tax which is represented by their policies. Half of it they never touch; it falls upon the householder direct. San Francisco and Salem do not pay for themselves. We all help pay for them. And next year San Francisco and Salem, risen from their ashes, may help to pay for other cities. There is but one way in which we can escape the periodical paying for one another, and that is for us all to begin rational building construction and then protect what we have builded against fire.

It is the ever-present conflagration hazard which makes any approach to scientific fire underwriting impossible. The conflagration hazard is not confined to any one city or state. It is present in every city and state in the Union. We have built largely of wood, and sooner or later we must pay the penalty unless we can find some way in which to protect our cities.

There is a way to solve this conflagration problem-not ab- 
solutely, but at least relatively. We cannot be expected to tear down our cities and rebuild them of fire-resisting material; the cities must be protected as they stand. In the heart of nearly every city there are streets crossing at right angles, along which for a very considerable distance are buildings of brick, stone and concrete. This shows a more or less complete Maltese cross of buildings which are not wood and which operate to divide the wooden-built district into quarter sections, and which might hold a fire in any one of these sections if they were equipped to do so. These brick and stone buildings are ordinarily valueless as firestops, because their windows are of thin glass and their window frames of wood. At Baltimore and San Francisco the conflagration attacked such buildings easily, breaking out the panes, consuming the frames, and converting every story of these brick structures into horizontal flues full of combustible contents. Brick and stone buildings are logical and capable firestops if the fire can be kept out of them. The small city that will trace out its Maltese cross of such buildings and equip them with metal window frames and wired glass will immediately possess the equivalent of substantial fire walls crossing at right angles in its center, dividing it into four sections. By such a simple, inexpensive, but yet strategic procedure many a city may save itself from the destruction which now awaits only the right kind of a fire on the right kind of a night.

I have referred in this plan merely to the smaller cities, but it is obvious that this form of protection is equally imperative in the brick, stone and concrete districts of all large cities where great values are housed in close proximity. Fires in the large cities entail an enormous waste because of the great values assembled there. We must come eventually to the equipment of all commercial, factory and office buildings with metal window frames and wired glass. This will mean the abolition of the conflagration hazard in our cities. Fires will then be unit fires, extinguished easily by a competent fire department within the building in which they originate; for the protection of window openings not only prevents fire from entering, but prevents fire from issuing out of the burning building. We may expect an occasional exceedingly hot fire to break down the defenses of an adjoining building, but it is obvious that a conflagration could not get under way among buildings of fire-resistive construction with properly protected window openings. 
Having thus fortified city buildings one against the other, extensive fires within individual structures can be prevented by the use of the now well-established automatic sprinkler system. The automatic sprinkler applies the water without the help of human agencies while the fire is still incipient. It will operate in a dense smoke as well as in a clear atmosphere. It will not throw excessive deluges of water in wrong places as the fire departments are continually forced to do. With our window openings protected and our buildings equipped with such extinguishers, the conflagration hazard in mercantile districts will be eliminated. There will then remain for consideration our immense residence districts constructed almost wholly of wood surrounding the mercantile centers, like fagots around a funeral pyre. We can lessen the loss here by the abolition of the use of wooden shingles.

The prohibition of the wooden shingle roof, which is now generally recognized as a conflagration breeder, is today almost universal within city fire limits, and from the more enlightened communities it is excluded altogether. Burning shingles can be carried great distances by the wind or draft of a conflagration, and when they alight in their turn upon other dry shingles, they make fearful havoc.

It will not be necessary to remove all shingle roofs immediately. An effective city ordinance might require all roofs constructed in the future to be of incombustible material, and that all roofs which shall hereafter require repair to the extent of one-third of their area shall be replaced with incombustible roofs. The modern shingle is thin, and the machinery which now makes it leaves a fuzzy surface which, after a period of drought, becomes like tinder. Without shingle roofs, flying brands would not be carried over the brick centers of the city by the wind.

Outside of the abolition of the shingle roof, we must look for the protection of our homes to the corrected habits of our people. We must look carefully after the heating apparatus of our homes, giving them the constant and necessary attention demanded by receptacles containing fire. The building of proper flues and chimneys is especially necessary in connection with residences. Then we must have a general revision throughout the country of our building codes. We must stop the building of a certain shoddy class of buildings and we must limit the height of all buildings. In 
Boston, buildings are limited to 125 feet. There is no reason why cities that can expand, and which are not bound by physical barriers, should follow the example of New York and erect absurdly high buildings. They inflict an enormous expense upon the city for fire protection.

There are other matters, however, to which we must give proper thought. Among them is the best use of the fire-fighting agencies which have been established and which are maintained at a great cost by our people.

The mental habits of a people are a vital factor in affecting social progress. It is the mental habit of our people to assume that fire departments are maintained for the exclusive purpose of extinguishing fires. It is obvious, however, that fire departments have large possibilities for service in preventing fires; a service which is, I regret to say, yet largely potential. In every fire department uniformed firemen should be regularly detailed for inspection service. Three or four hours a week for each man, going into basements, attics, courts and alleys, keeping down accumulations of rubbish - which spring up over night-locating the storage of inflammable oils and explosives, would keep the city clean of its most persistent fire dangers. Every fireman should in turn cover every section in the course of six months. One would thus check up the inspections of the other, and local conditions would become a matter for educative conversation about headquarters.

There is, however, a most important result to be achieved by such an inspection system over and beyond keeping the city clean; and that is the education of the fire-fighters in the exact physical character of the city. To know exactly which passageways are open and which are closed; to know which are fire walls and which are not; to have a mental picture of the exposures, the windows, the roof openings, the cornices, and all the other physical details important in fire-fighting, would so heighten the team work of a department that, like expert swordsmen, they could make their thrust without loss of time straight at the vulnerable part. There are a few cities in the United States where such practice, partially in effect, has already demonstrated it’s singular efficiency. The citizens of every town and city should demand this sort of service from its fire department.

Then we must begin to place the responsibility upon the in- 
dividual for fires. It is difficult to do that, I know, and yet it can be done. In France, if you have a fire and that fire damages your neighbor's property you have to pay your neighbor's loss. That is very educative! It would be a very good thing if we had such a law in America. We can fix responsibility, however, and we can change our attitude of mind toward the man who has fires. When we look upon the man who has a fire as one who has done an unneighborly thing, as one who is a public offender unless he can prove that he was in no way responsible for that fire, then we will have begun to make headway. We must have inquiry into the causes of all fires, not merely an inquiry into the fire which is suspected to be the work of some incendiary. Nearly every fire is the result of some carelessness; and the careless man must be held up to public criticism as a man who has picked the pockets of the rest of us; because that is what it is in its last analysis. When we get fire marshals in every state or province who shall inquire into the causes of fires, I believe we will begin to correct our personal habits in respect to the things that cause fires. In New York City and in Cleveland, Ohio, the man who ignores a fire prevention order must pay the city for the services of the fire department if fire occurs on his premises. This is also the law in the State of Pennsylvania for cities of the second class.

In conclusion I have set down certain specific suggestions to property owners which, in view of the above, may help a personal consideration of this problem, and an understanding of what citizens may do to solve it, both for their own good and the good of the cities in which they live.

Property owners can do good service both in their own interest and in the interest of their community in this matter by first caring for the fire hazard of their own property, and then helping in any general local movement to eliminate the fire hazards from their city.

In a study of one's own property he should give specific attention to the following items:

Exposure Hazard. If your premises are surrounded or exposed to property that is inflammable or otherwise hazardous, you are paying for this danger in your insurance rate. Study your location and your exposure hazard and the reasonable means of bettering your own property (such as fireproofing doors and windows and outside 
walls, extending fire walls above roof, non-combustible roofs, etc.), so as to minimize this physical exposure hazard.

Construction. A large part of your insurance rate is always based on deficiencies in physical construction of your property. Study this (such as unprotected and horizontal openings, too large areas undivided by fire walls, concealed spaces, etc.) and ascertain how they may be reasonably remedied, and how such improvement will reduce your insurance rate.

Protection. The best located and constructed property in the world without adequate fire alarm and extinguishing facilities may suffer from fire either in building or contents, or both. Burning contents often ruin so-called fireproof buildings. Study the deficiencies of your property in this respect and better them (by installing metal waste and ash cans, fire buckets, chemical extinguishers, automatic sprinkler or standpipe systems, etc.), and you may find the investment highly profitable in the reduced hazard and rate.

Occupancy. Every business has inherent in it certain dangerous fire hazard characteristics. Study the nature of your business and properly care for and isolate material or processes which may unduly occasion or accelerate fires.

Equipment. Virtually all property must be heated, lighted and ventilated, and all this equipment, in addition to special apparatus required by almost every business, has fire hazard. Study the character of your equipment thoroughly before purchasing, and improve that which you now have.

Management. Keep your property clean. Half of all American fire waste comes from careless accumulation of dirt and rubbish, and disorder. Teach your people cleanliness and order, and organize them to detect and extinguish fire, and how to call the public fire department quickly when necessity requires.

Every owner can apply in his factory, apartment house, warehouse or home the foregoing correctives, which constitute the essentials of fire prevention. He can also join any other good movements in community action to carry out this program, and to study and get prepared and enforced reasonable legal regulations whereby such correctives may be demanded in the law, and finally can back up public officials in seeing that they are applied.

The American people are not dull in comprehension, nor are 
they slow to act once the necessities of a situation are made clear to them. The awakening manifested by the annual observance of "Fire and Accident Prevention Day" in many of the cities of the United States, by the appointment of fire marshals and the amendment of fire marshal laws; and by the teaching of the fire hazards in many public schools, indicates that we as a people will not much longer tolerate our pitiful impoverishment by fire waste. It is true that so long as our wooden cities stand they must occasionally suffer disastrous fires, with, oftentimes, shocking loss of life; but with the growing disposition to hold our citizens personally responsible for their carelessness, many of our most prolific causes of fire will disappear.

Our civilization grows daily more complex. Every man's life is becoming more inextricably linked with the lives of others. An injury to one is increasingly an injury to all. Out of a proper realization of these facts is coming a larger sense of civic responsibility. As citizens of a common country and brothers of a great international family, we may some day evolve a civilization in which there shall be no waste and in which the thought of the common good shall be the profoundest impulse in the hearts of our people. 